\title{
Evaluation of an Organic Treatment Scheme against Eurytoma schreineri Schreiner
}

\author{
Claudiu MOLDOVAN ${ }^{1 *}$, Ioan ZAGRAI ${ }^{1}$, Luminița ZAGRAI ${ }^{1}$, Aurel MAXIM ${ }^{2}$, Georgeta GUZU ${ }^{1}$ \\ ${ }^{1}$ Fruit Research \& Development Station Bistrița, 3 Drumul Dumitrei Nou, Bistriţa, 420127, Romania \\ ${ }^{2}$ Faculty of Agriculture, University of Agricultural Sciences and Veterinary Medicine Cluj-Napoca, 3-5 \\ Manastur St, 400372 Romania \\ *corresponding author: clau92moldovan@gmail.com
}

BulletinUASVM Horticulture 77(2) / 2020

Print ISSN 1843-5254, Electronic ISSN 1843-5394

DOI:10.15835/buasvmcn-hort: 2020.0047

\begin{abstract}
The experiment aimed to evaluate some of organic products within a treatment scheme against Eurytoma schreineri Schreiner, on two different plum varieties: Stanley and Reine Claude d'Althan. An experimental scheme of organic treatments by using seven organic products with insecticidal effect was developed and used for evaluation in the field. There were three variants taken into account: organic, conventional and untreated, used as control. Each variant consisted of eight trees belonging to Stanley and Reine Claude d'Althan cvs., four trees for each variety. The frequency occurring of Eurytoma schreineri was evaluated along two consecutive years (2019-2020). Overall results confirmed the sensitivity of Stanley cv. to Eurytoma. schreineri. On the other hand, the results showed that the organic scheme developed was unsatisfactory and there is a risk of considerable losses for farmers who opt for this kind of scheme.
\end{abstract}

Keywords: Eurytoma schreineri, organic products, pest, plum

\section{Introduction}

In spite of a significantly higher price of organic fruits in comparison with the conventional ones, there is an increasing demand for fruits with no pesticide residues. In this context more and more farmers directed the attention to enlarge the area of organic crops (Neelesh and Attika, 2015; Manoj, 2017). Organic treatments for prevention and control of the diseases and pests are few on the market, and their effectiveness is not fully known yet. This situation exposes the new organic orchards to an imminent risk of disease and pest control, that can affect the quality and quantity of fruits. Eurytoma schreineri is one of the most important pests that can cause significant losses on plum (Maxim, 1997, 2008). The pest causes considerable damage up to $90 \%$ when no treatment is applied ( Tămaş Rodica et al., 2009).
That is why an effective phytosanitary program is needed for its control. Eurytoma schreineri develops only one generation per year, and the affected fruits fall prematurely starting with June (Gullan and Cranston, 2014).

\section{Materials and methods}

The experiment was organized in the field, where three variants were delimited, depending on the treatments used: conventional, ecological and untreated control, each variant being composed of eight trees. Four trees of each, Stanley and Reine Claude d'Althan cvs. per treatment variant were used. A total of seven treatments in conventional and ecological variants were applied during each year. Ecological insecticides used in this study were: OVIPRON TOP (highly refined, paraffinic mineral oil) 2,5\%, KONFLIC (50\% Potassium salt 
from vegetable oil extract and 50\% bitter Quassia spp. extract) $0.3 \%$, DEFFORT (plant extract from the Fabaceae family and microelements) 0.3\%, OLEORGAN (vegetable oils) 0.3\%, BACTOSPEINE DF (54\% Bacillus thuringiensis subsp. Kurstaki) 0.1\%, ALGASIL (extract Ascophyllum nodosum plus silicon and potassium) 0.5\%, PREV-AM (Orange oil $60 \mathrm{~g} / \mathrm{l}$ ) $0.8 \%$. Versus were used the following conventionalinsecticides:MOSPILAN (acetamiprid, $200 \mathrm{~g} / \mathrm{kg}$ ) $0.02 \%$, CALYPSO (tiacloprid, $480 \mathrm{~g} / \mathrm{l}$ ) $0.02 \%$, KARATE ZEON (lambda-cyhalohrin, 50g/l) $0.015 \%$, ACTARA (thiamethoxam, $250 \mathrm{~g} / \mathrm{kg}$ ) $0.01 \%$, MOVENTO (spirotetramat, $100 \mathrm{~g} / \mathrm{l}$ ) $0.19 \%$. The concentrations used are those recommended by the manufacturers (Tab. 1).

For a precise determination all fruits from each variant were firstly counted, separately into canopy and falled on the ground. Then, it was determined the fallen fruits affected by Eurytoma schreineri in relation to the physiological fall on both Stanley (Fig. 1) and Reine Claude d'Althan cvs. (Fig. 2) by opening all the fallen fruits using a vise. The number of fruits affected by Eurytoma schreineri were reported to the total number of fruits (on the tree plus those affected), thus the frequency of the attack of Eurytoma schreineri was determined.

\section{Results and discussions}

The results in the variant treated with conventional products showed that the frequency of $E$. schreineri attack on the Stanley variety was $5 \%$ in 2019 and 3.5\% in 2020. The Reine Claude d'Althan variety recorded $1 \%$ frequency of Eurytoma schreineri in both years, 2019 and 2020.

The variant treated with ecological products revealed an attack of E. schreineri between 12\% (2019) and 28\% (2020) on Stanley variety, while on Reine Claude d'Althan variety the frequency attack was between 3\% (2019) and 4\% (2020).

The untreated variant recorded a frequency of Eurytoma schreineri attack of $17 \%$ in 2019 and $32 \%$ in 2020 on the Stanley variety, and of $4 \%$ in both years, on Reine Claude d'Althan variety (Fig. 3).

The average attack of Eurytoma schreineri in the two consecutive years of study was $4 \%$, on conventional variant on Stanley and $1 \%$ on Reine Claude d'Althan variety, respectively. The frequency of attack on the variant with ecologically products, was $20 \%$ on Stanley, while on Reine Claude d'Althan, it was only $4 \%$. The average frequency attack on untreated variants in the period of 20192020 was $25 \%$ on Stanley variety, and only $4 \%$ on Reine Claude d'Althan variety (Fig. 4).

Table 1. Treatment schemes with conventional and ecological products applied in the plum orchard (2019-2020)

\begin{tabular}{clcc}
\hline No. & \multicolumn{1}{c}{ Phenophase } & Conventional treatment & Organic treatment \\
\hline I & Sprouting & Mospilan $(0,02 \%)+$ Toil $(0,5 \%)+$ Champ & $\begin{array}{c}\text { Ovipron Top }(2,5 \%)+\text { Bordeaux } \\
\text { Mixture }(0,75 \%)\end{array}$ \\
\hline II & Inflorensce emergence & Signum $(0,05 \%)$ & Mimox $(0,3 \%)$ \\
\hline III & Flower fading & Calypso $(0,02 \%)+$ Folicur Solo $(0,075 \%)$ & Laser 240 SC $(0,06 \%)+$ Funrres \\
& & Mospilan $(0,02 \%)+$ Karate Zeon $(0,015 \%)$ & Konflic $(0,3 \%)+$ Deffort $(0,3 \%)$ \\
\hline IV & $7-10$ days after treatment III & + Movento $(0,19 \%)+$ Dithane $(0,2 \%)$ & Oleorgan $(0,3 \%)+$ Zytron $(0,15 \%)$ \\
\hline V & $7-10$ days after treatment IV & Actara $(0,01 \%)+$ Score $(0,02 \%)$ & Bactospeine Df $(0,1 \%)+$ Laser \\
\hline VI & $7-10$ days after treatment V & Calypso $(0,02 \%)+$ Bravo 500 SC $(0,25 \%)$ & Algasil $(0,5 \%)+$ Zytron $(0,15 \%)$ \\
\hline VII & $7-10$ days after treatment VI & Mospilan $(0,03 \%)+$ Topsin $(0,07 \%)$ & Prev-Am $(0,8 \%)+$ Mimox $(0,3 \%)$ \\
\hline VIII & $7-10$ days after treatment VII & Signum $(0,05 \%)$ & Garex $(0,2 \%)$ \\
\hline IX & $7-10$ days after treatment VIII & &
\end{tabular}




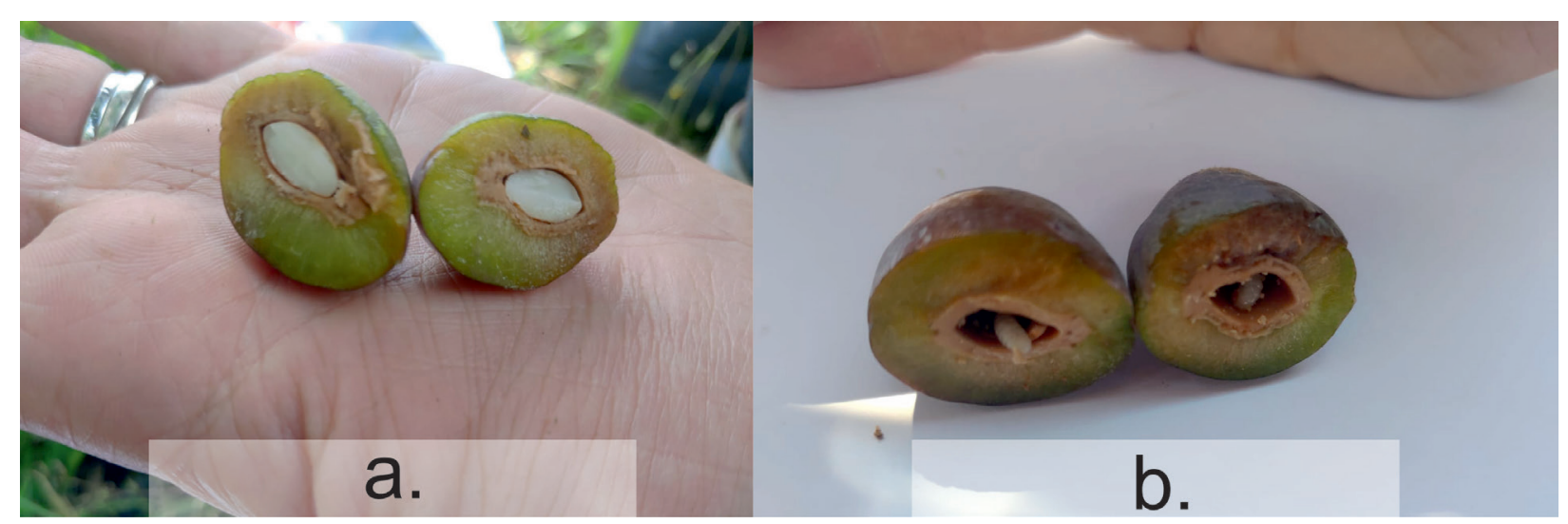

Figure 1. (a) Physiological fall, (b) fruits affected by E. schreineri on Stanley variety
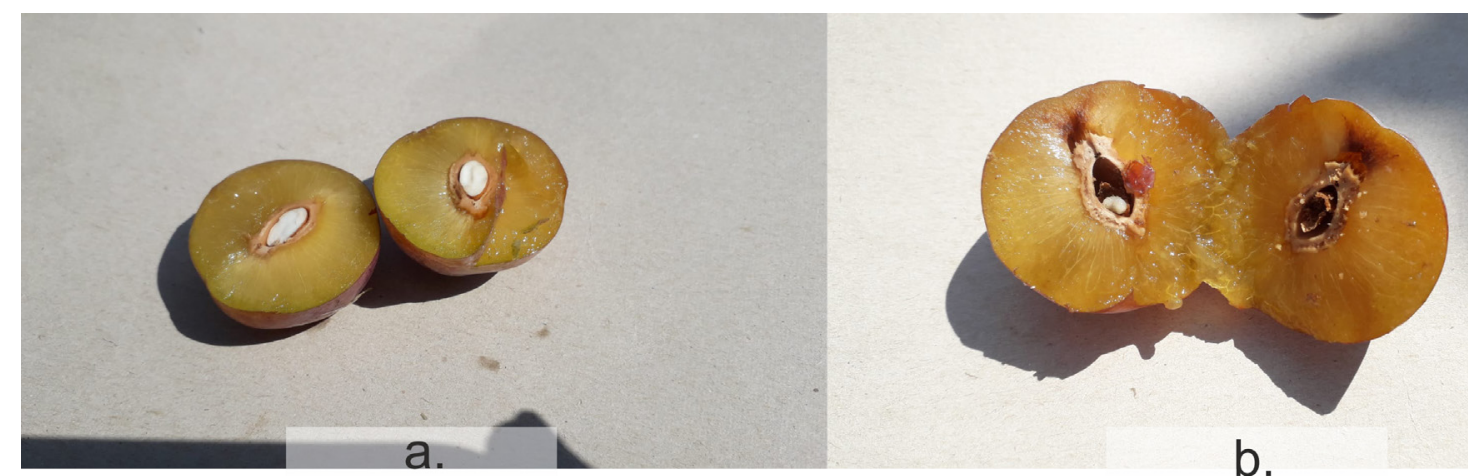

b.

Figure 2. (a) Physiological fall, (b) fruits affected by E. schreineri on Reine Claude d'Althan variety

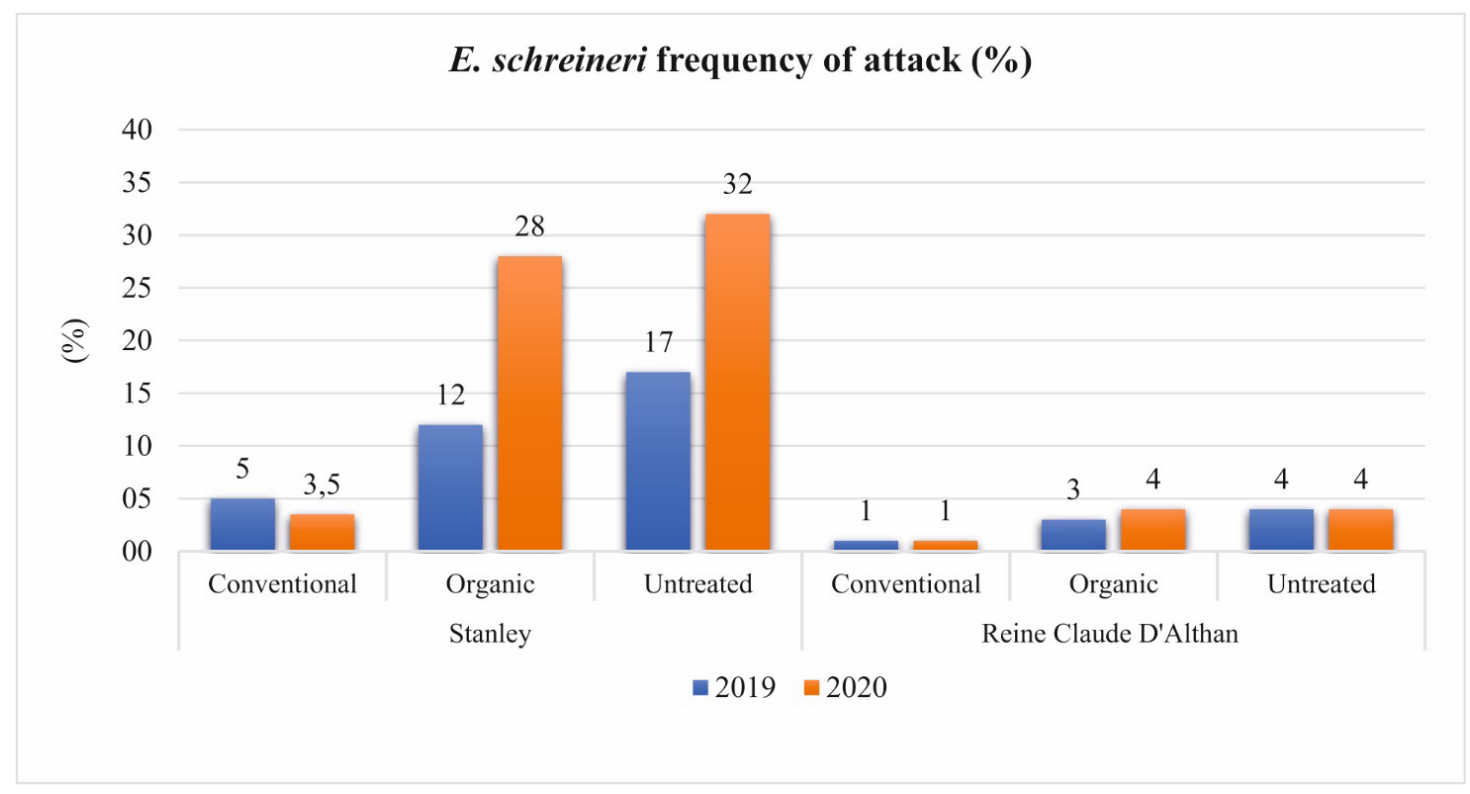

Figure 3. Frequency of E. schreineri attack over two years 


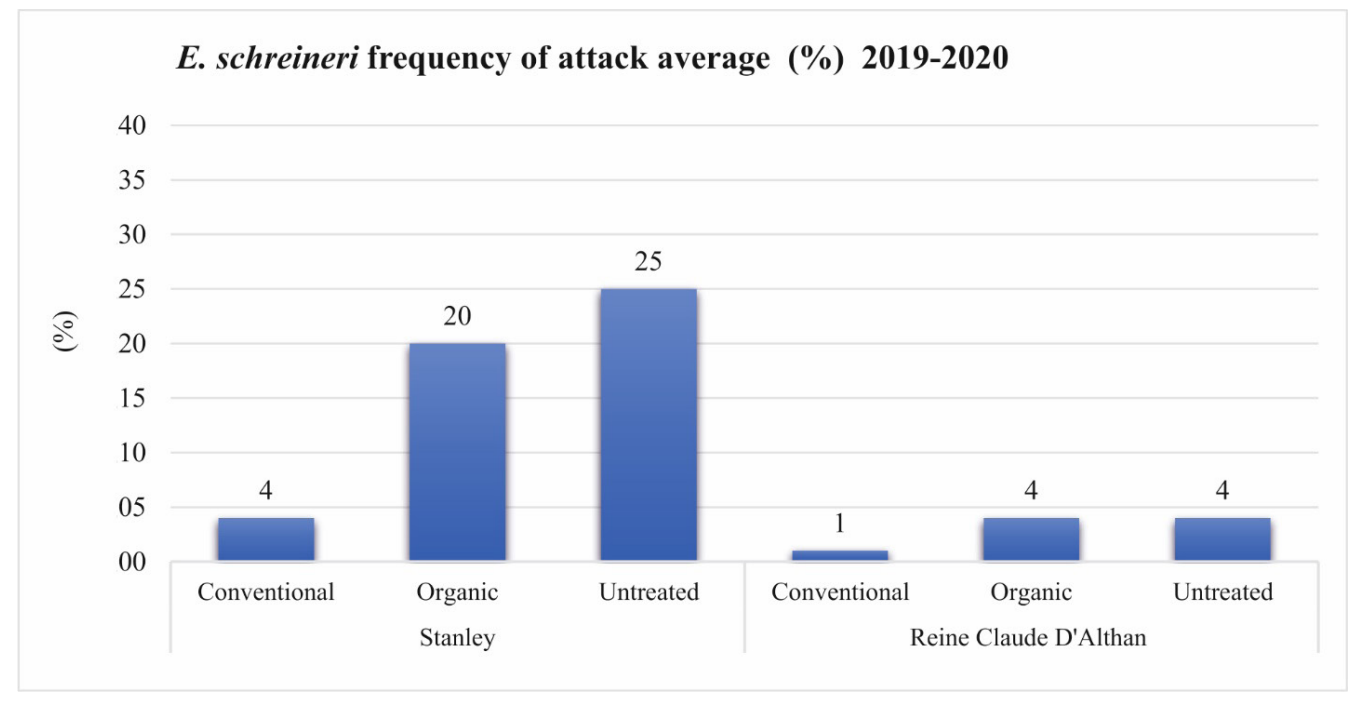

Figure 4. Average frequency of attack of Eurytoma schreineri (2019-2020)

Overall results revealed that the ecological scheme developed against Eurytoma schreineri was unsatisfactory. On the other hand, our results confirmed that Stanley is a sensitive plum variety to the attack of Eurytoma schreineri, and can not be controlled by using such a scheme of ecological treatments. Instead, the use of resistant or tolerant varieties, such as Reine Claude d'Althan can be a better choice for an organic crop.

Although the results obtained along the two consecutive years (2019-2020) are not very encouraging, studies must be continued by looking for an improvement scheme. Eurytoma Schreineri is a pest which live inside the plum fruit, this fact create difficulties in ecological protection, because they have only a contact effect. Therefore, increasing the number of treatments with organic products in comparison with conventionals during the flight period could improve the results. Also, on small isolated plum orchards, gathering fallen fruit and destroying them could be an effective method of control, given that the larva does not migrate into the soil but remains in the kernel until the following spring.

\section{Conclusions}

The overall results showed that Eurytoma schreineri pest is still problematic in organic crops when sensitive varieties are used. Its control only through the use of organic products does not have the desired effect under the treatment scheme presented and there is a risk of considerable losses from an economic point of view for farmers who opt for such crops. In order to get a significant diminishing of the losses caused by Eurytoma schreineri is necessary an improved scheme of ecologic phytosanitary treatment, application of agrotechnical control measures and the choice of resistant varieties.

\section{Acknowledgement}

This work was supported by a grant of the Romanian Ministry of Research and Innovation, PCCDI-UEFISCDI, project number PN-III-P1-1.2PCCDI-2017-0662, 12PCCDI/2018, within PNCDI III.

\section{References}

1. Gullan PJ, Cranston PS (2014), The Insects: An Outline of Entomology 5th Edition, WILEY Blackwell, New Jersey.

2. Manoj K (2017). Future Approach to Organic Agriculture, Brajesh Kumar Tiwari Media Centre, Bihar.

3. Maxim A (1997). Comportarea unor soiuri şi portaltoi de prun la atacul dăunătorului Eurytoma schreineri, în condiţiile de la Bistriţa. Bul. Doc. Inf. Hort. al SRH fil. BN 14: 23-25.

4. Maxim A (2008). Ecologie Generală și Aplicată, Risoprint, Cluj-Napoca (Chapter 3).

5. Neelesh N, Attika G (2015). Organic farming: a new revolution in agriculture, Journal of Agroecology and Natural Resource Management, 2: 2394-0794.

6. Tămaș R, Odica T, Oltean, I, Florian T (2009), Studies on the Biology and the Ecology Pest Eurytoma Schreineri (Waspy Plum Seed), in Mureș County, Buletin USAMV-CN, H, 66(1): 229-232. 